\title{
Morphological Diversity of Soft Palate in Nepalese Population: A Retrospective Cephalometric Study
}

\author{
Dr Chandan Upadhyaya,' Dr Iccha Neupane,2 Dr Binam Sapkota, ${ }^{3}$ Dr Shatakshi Srivastava4 \\ 'Assoc Prof, Dept of Oral \& Maxillofacial Surgery, 2Dental Surgeon, \\ ${ }^{3}$ Asst Prof, Dept of Prosthodontics, 4Lecturer, Dept of Community \& Public Health Dentistry, \\ Kathmandu University School of Medical Sciences, Dhulikhel, Nepal \\ Correspondence: Dr Chandan Upadhyaya; Email: updch@yahoo.com
}

\section{ABSTRACT}

Introduction: Soft palate is a fibromuscular portion constituting the back of roof of the mouth which is essential for phonation, deglutition, respiration and velopharyngeal competence.

Objective: To study various morphologies of soft palate, difference in proportion of each type and their differencesamong gender and agegroups in Nepalese sample.

Materials \& Method: Aretrospective study was conducted on patients seeking orthodontic treatment. 263 lateral cephalograms were classified on the basis of radiographic appearance. Analysis was done using SPSS (version 20.0). Pearson chi square and descriptive statistics were performed and level of significance was set at $p<0.05$.

Result: In the order of occurrence; rat tail type of soft palate was most prevalent followed by leaf type, butt type, straightline, crooked type and $S$ shaped. There was no significant difference between male and female subjects $(p=0.338)$ and through age groups $(p=0.998)$.

Conclusion: The study highlights various types of soft palate present in Nepalese sample which will help as a reference for research pertaining to cleft palate/ velopharyngeal closure and in obstructive sleep apnoea syndrome in Nepalese population.

Key-words: digital lateral cephalometry, morphology, soft palate

\section{INTRODUCTION}

The oral cavity has various functions including respiratory, nutritional and communicative. The palate is the roof of the mouth and comprises of an anterior bony hard palate and posterior muscular portion. Soft palate is a fibromuscular portion constituting the back of roof of the mouth and does not contain bone. The hard and soft palate are easily palpable and identified by change in colour.' Soft palate plays an important role in phonation, deglutition, respiration and velo-pharyngeal competence. ${ }^{2}$ The palate is formed by the fusion two palatal processes and fronto-nasal process. In later stage, the mesoderm in the palate undergoes intra-membranous ossification to form the hard palate whereas the posterior part doesnot undergo ossification and remains as soft tissue..$^{3-5}$

Theanatomy of the soft palate plays animportant role in velopharyngeal closure which is a sphincteric mechanism constituting of velar and pharyngeal components. The movement separates the oral cavity from nasal cavity during deglutition and speech. When the velum and lateral and posterior pharyngeal walls fails to separate two cavities, velopharyngeal incompetence (VPI) occurs. It participates in many oral functions especially velopharyngeal closure which is related to normal function of sucking, swallowing, and pronunciation. ${ }^{6}$ This incompetency can result into many malfunctions especially Obstructive Sleep Apnoea (OSA).

You $M$ et al documented the variation in normal velar morphology and classified them into six different categories; ${ }^{7}$ which have been employed in the present study. The objective of this study is to classify various morphologies of soft palate, difference in proportion of each type and also the difference between gender and age groups in Nepalese sample.

\section{MATERIALS AND METHOD}

The retrospective study was conducted from July 2016 to February 2017. A total of 263 lateral cephalograms were collected randomly from patients who had visited Department of Orthodontics and Department of Oral 
Medicine \& Radiology, Dhulikhel Hospital. Patients seeking orthodontic treatment for malocclusion without any speech abnormality orany other syndromes or diseases within the age rangeof 18 to 40 years were included in the study. Among them 92 weremale and 171 were female. Participants with head \& neck anomalies, intraosseous pathologies, history of trauma or any surgery, images with positioning errors, magnification or distortion were excluded from the study. The examination and classification ofsoft palate on lateral cephalograms was done bya single trained examiner. The panoramic $X$ Ray unit used was Planmeca ProMax, Finland with the tube potential 80-84 kV, tube current $16 \mathrm{~mA}$, and exposure time $2 \mathrm{sec}$.

In this study, soft palate was classified according to You $\mathrm{M}$ et al. On the basis of radiographic appearances; categorization ofsoft palate was done into following six types$^{7}$ (Figure 1).
Type 1: Leaf / Lanceolate shaped: The middle portion of the soft palate elevated to both nasal and oral sides.

Type 2: Rat-tail shaped: The soft palate showing inflated anterior portion and free margin with an obvious coarctation.

Type 3: Butt-like: The soft palate showing a shorter and fatter velum appearance with no distinct difference of width of the anterior portion to the free margin.

Type 4: Straight line shaped.

Type 5: S-shaped/distorted soft palate.

Type 6: Crooked appearance: The soft palate with posterior portion crooks antero-superiorly.

Pearson chi square test was used to compare the groups and descriptive statistics was portrayed for frequency distribution. Level of significance was set at $p<0.05$. All Analyses were done using SPSS (version 20.0).

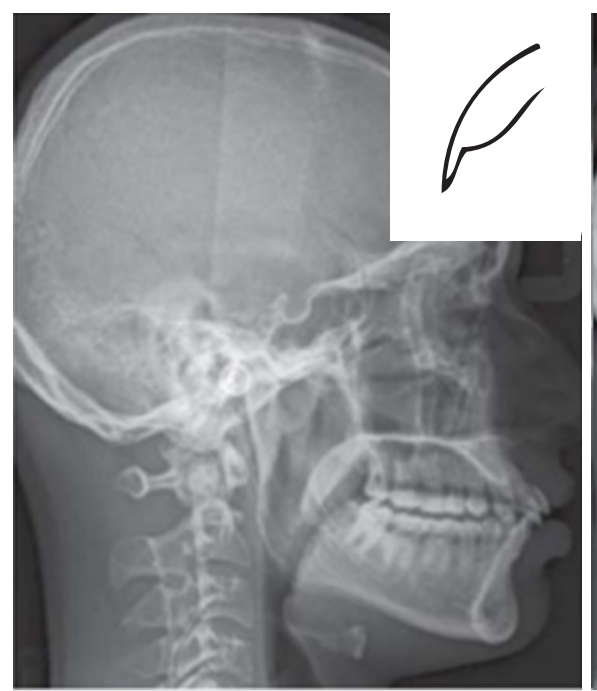

Type 1: Leaf shaped/ Lanceolate shaped

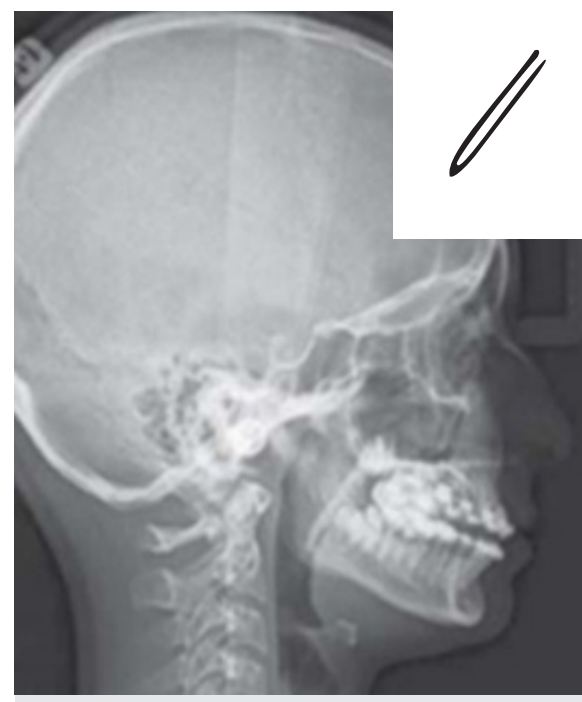

Type 4: Straight line shaped

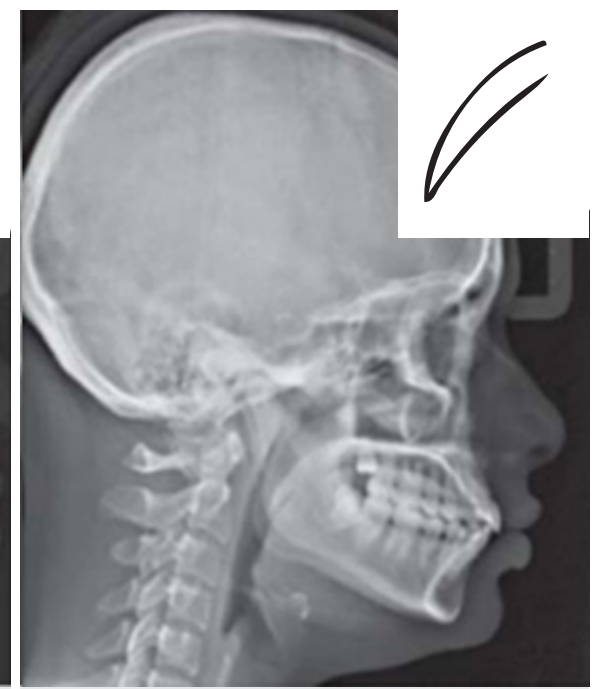

Type 2: Rat-tail shaped

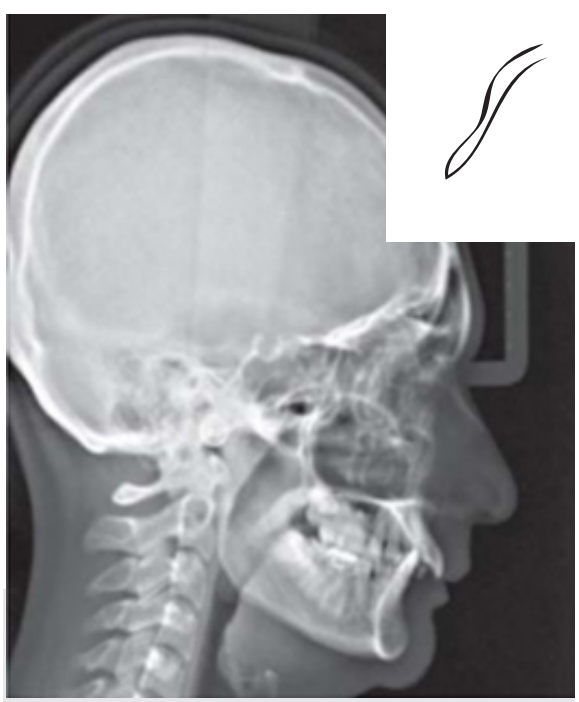

Type 5: S-shaped/distorted soft palate

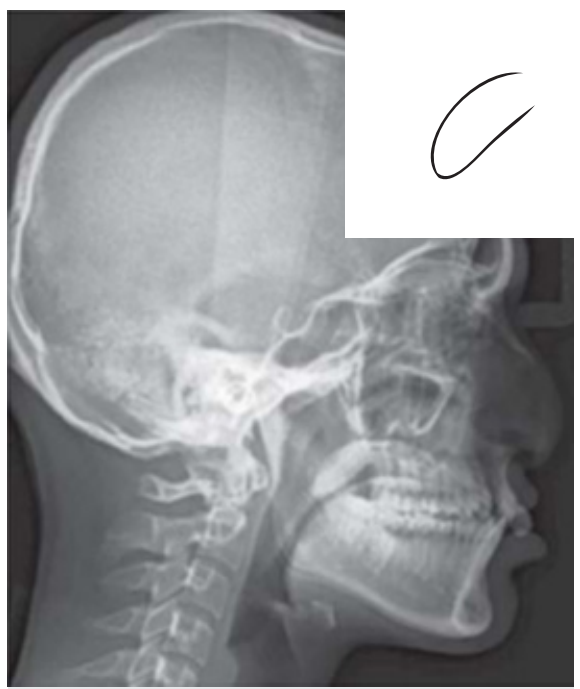

Type 3: Butt-like

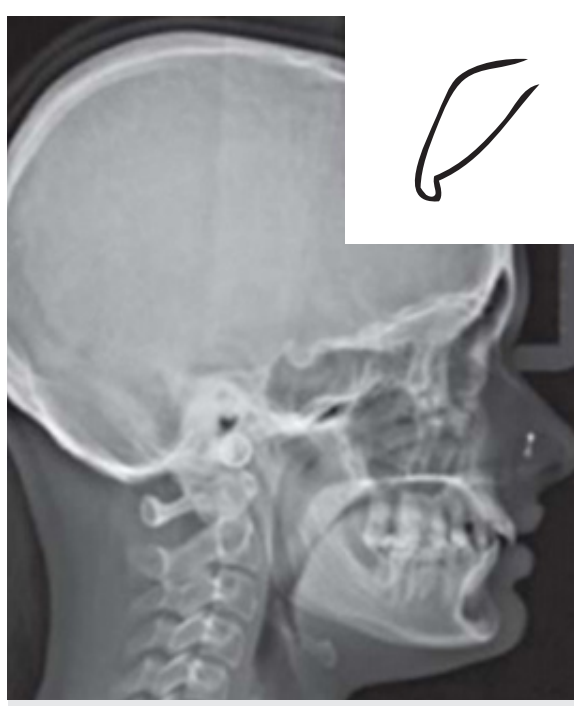

Type 6: Crooked appearance

Figure:1: Various types of soft palate according to You $M$ et al 


\section{RESULT}

In the present study, the age group of patient ranged from 18-40 years with the mean age of 27.70 years. Among various types of soft palate, maximum number of participants had rat tail type of soft palate (35.0\%), followed by leaf type (20.2\%), butt type (14.4\%) and straight line (13.7\%), crooked type (10.3\%) and S shaped (6.5\%) (Table 1).

The gender comparison showed almost equal proportion of male and female in each type of soft palate with no significant difference between the groups $(p=0.338)$ (Table 2).

The age-wise comparison ( $<20$ years, $21-30$ years and 3140 years) showed almost equal proportions in each type of soft palate with no significant differences among the groups ( $p=0.988$ ) (Table 3$)$.

\section{DISCUSSION}

The lateral cephalogram is the most common diagnostic radiograph used in clinical orthodontics. Cephalometric analysis is a commonly accepted technique for the evaluationof soft palate in both normal individuals and in cleft palate and Obstructive sleep apnea (OSA) cases. It is used because of its easy availability and cost effectiveness. The morphology of soft tissues like soft palate can be clearly observed on lateral cephalogram. ${ }^{8}$

The diagnosis of a plethora of neurologic, inflammatory, and neoplastic disorders of the adult soft palate can be assessed by radiographic methods. The dimensional analysis of the soft palate and it surrounding structures (velar length and width) has been studied extensively in the past; but the types of velar morphology which is the most obvious reason of the different dimensions on the

Table 1: Distribution of various types of soft palate

\begin{tabular}{|l|c|c|}
\hline \multicolumn{1}{|c|}{ Types of soft palate } & Frequency $(\mathbf{n})$ & Percent (\%) \\
\hline Rat tail & 92 & 35.0 \\
\hline Leaf & 53 & 20.2 \\
\hline Butt type & 38 & 14.4 \\
\hline Straight line & 36 & 13.7 \\
\hline Crooked & 27 & 10.3 \\
\hline S shaped & 17 & 6.5 \\
\hline Total & 263 & 100.0 \\
\hline
\end{tabular}

Table 2: Comparison of type of soft palate with gender

\begin{tabular}{|c|c|c|c|c|c|c|c|c|c|}
\hline \multirow{2}{*}{\multicolumn{2}{|c|}{ Gender }} & \multicolumn{6}{|c|}{ Type of Soft palate } & \multirow{3}{*}{$\begin{array}{c}\text { Total } \\
92 \\
\end{array}$} & \multirow{2}{*}{$\begin{array}{l}\text { p-Value } \\
\text { (2 sided) }\end{array}$} \\
\hline & & \multirow{2}{*}{$\begin{array}{c}\text { Leaf } \\
20\end{array}$} & \multirow{2}{*}{$\begin{array}{c}\text { Rat tail } \\
27\end{array}$} & \multirow{2}{*}{$\begin{array}{c}\text { Butt type } \\
11\end{array}$} & \multirow{2}{*}{$\begin{array}{c}\text { Straight line } \\
14\end{array}$} & \multirow{2}{*}{$\begin{array}{c}\text { S shaped } \\
6\end{array}$} & \multirow{2}{*}{$\begin{array}{c}\text { Crooked } \\
14\end{array}$} & & \\
\hline Malo & $\mathrm{N}$ & & & & & & & & \multirow{6}{*}{0.338 (NS) } \\
\hline vicice & $\%$ & $21.7 \%$ & $29.3 \%$ & $12.0 \%$ & $15.2 \%$ & $6.5 \%$ & $15.2 \%$ & $100.0 \%$ & \\
\hline \multirow{2}{*}{ Female } & $\mathrm{N}$ & 33 & 65 & 27 & 22 & 11 & 13 & 171 & \\
\hline & $\%$ & $19.3 \%$ & $38.0 \%$ & $15.8 \%$ & $12.9 \%$ & $6.4 \%$ & $7.6 \%$ & $100.0 \%$ & \\
\hline \multirow{2}{*}{ Total } & $\mathrm{N}$ & 53 & 92 & 38 & 36 & 17 & 27 & 263 & \\
\hline & $\%$ & $20.2 \%$ & $35.0 \%$ & $14.4 \%$ & $13.7 \%$ & $6.5 \%$ & $10.3 \%$ & $100.0 \%$ & \\
\hline
\end{tabular}

Table 3: Comparison of type of soft palate with age group

\begin{tabular}{|c|c|c|c|c|c|c|c|c|c|}
\hline \multirow{2}{*}{\multicolumn{2}{|c|}{ Gender }} & \multicolumn{6}{|c|}{ Type of Soft palate } & \multirow{3}{*}{$\begin{array}{c}\text { Total } \\
59 \\
\end{array}$} & \multirow{2}{*}{$\begin{array}{l}\text { p-Value } \\
\text { (2 sided) }\end{array}$} \\
\hline & & Leaf & Rat tail & Butt type & Straight line & S shaped & Crooked & & \\
\hline \multirow{2}{*}{$>20 \mathrm{yrs}$} & $\mathrm{N}$ & 10 & 21 & 9 & 9 & 5 & 5 & & \multirow{8}{*}{$\begin{array}{l}0.988 \\
\text { (NS) }\end{array}$} \\
\hline & $\%$ & $16.9 \%$ & $35.6 \%$ & $15.3 \%$ & $15.3 \%$ & $8.5 \%$ & $8.5 \%$ & $100.0 \%$ & \\
\hline \multirow{2}{*}{$\begin{array}{l}21-30 \\
\text { yrs }\end{array}$} & $\mathrm{N}$ & 22 & 34 & 15 & 12 & 7 & 9 & 99 & \\
\hline & $\%$ & $22.2 \%$ & $34.3 \%$ & $15.2 \%$ & $12.1 \%$ & $7.1 \%$ & $9.1 \%$ & $100.0 \%$ & \\
\hline \multirow{2}{*}{$\begin{array}{l}31-40 \\
y r s\end{array}$} & N & 21 & 37 & 14 & 15 & 5 & 13 & 105 & \\
\hline & $\%$ & $20.0 \%$ & $35.2 \%$ & $13.3 \%$ & $14.3 \%$ & $4.8 \%$ & $12.4 \%$ & $100.0 \%$ & \\
\hline \multirow{2}{*}{ Total } & $\mathrm{N}$ & 53 & 92 & 38 & 36 & 17 & 27 & 263 & \\
\hline & $\%$ & $20.2 \%$ & $35.0 \%$ & $14.4 \%$ & $13.7 \%$ & $6.5 \%$ & $10.3 \%$ & $100.0 \%$ & \\
\hline
\end{tabular}

NS: Not significant 
soft palate has frequently been left unexplored. Even after closure of the soft tissue defect in cleft patients, normal function of the softpalate is frequently not achieved and velopharyngeal insufficiency (VPI) with hypernasal speech follows thereafter in more than 30\% patients. ${ }^{9-12}$ One of the several hypotheses proposed by Cohen et al suggested that; this surgically successful yet functionally compromised repair may be the difference in morphology of the soft palate and other associated structures in these patients from that of the normal subjects. Hence, presurgical evaluation of soft palate morphology aid in the success ofsurgery. ${ }^{13-16}$

In the present study, Type 2 rat tail shape was most frequent type $(35.0 \%)$, which is similar to study done by Samdani et al. ${ }^{17}$ This was followed bythe prevalence of Type 1 Leaf shaped (20.2\%). However in many studies; most common type of soft palate reported was Leaf type..$^{18,19,4}$ The leaf shape which is found as second common in our study was previously described as classic velar morphology in literature. This variation could be due to the fact that most of our study cases had malocclusions requiring orthodontic treatment.

In other studies; the most common type of morphological variant of soft palate was reported to be butt-shape and $S$ shaped. ${ }^{20,21}$ These variations in types of soft palate could be population related trait. Probably, there are not many studies done in Nepali population that evaluate the types of soft palate.

The recurrent occlusion of the upper airways resulting from the inspiratory collapse of the pharyngeal walls during sleep results in Obstructive sleep apnea (OSA). Etiological or predisposing factors for OSA are still not clearly known. Incidence of OSA is higher in middle-aged adults. Studies have reported that the pharyngealmorphology is not completely established duringchildhood and adolescence, which changes throughout the adult life. There is a tendency towards longer and thickersoft palate and narrower oropharynx during adulthood, which may explain the possible increased incidence of OSA and related disorders occurring later in life. The S shape which was described as hooked appearance of soft palate by Pepin et al was found in $6.5 \%$ of our cases. They found the "hooked" appearance of soft palate in patients who were awake and this appearance of soft palate is associated with high risk of obstructive sleep apnea syndrome (OSAS). ${ }^{22}$

The difference among age and gender groups with different shapes of soft palate was not statistically significant in the present study, conforming to other studies as well. ${ }^{19,18,23}$

\section{CONCLUSION}

Soft palate is an important structure in velopharyngeal closure and provides information for diagnosis, prognosis and treatment in individuals with cleft palate and in obstructive sleep apnoea syndrome. The present study helps as a reference for research pertaining to cleft palate/ velopharyngeal closure and in obstructive sleep apnoea syndrome in Nepali population.

\section{OJN}




\section{REFERENCES}

1. Standring S. Grays Anatomy: The anatomical basis for clinical practice. 40 ed., London: Elsevier Churchill Living Stone Publishing Company, 2008; pp. 564-75.

2. Johns D, Rohrich R, Awada M, Velopharyngeal incompetence: A guide for clinical evaluation. $2003 ;$ Vol 7, p. 112.

3. Chaurasia B, Human anatomy- Head, Neck and Brain, 5 ed., Vol. 3, New Delhi: CBS Publisher, 2010 ; pp. $210-2$.

4. Kumar K, Gopal K. Morphological variants of soft palate in normal individuals: A Digital Cephalometric Study. J Clin Diagn Res. 201 1 ; 5(6): 1310-3.

5. Datta A. Essentials of human anatomy. 5 ed., Current Books Int'l, 2012, pp. 274-8.

6. Moore K, Agur A. Essential Clinical Anatomy. Philadelphia: Williams \& Wilkins, 2002.

7. You M, Li X, Zhang J, Wu H, Liu Y, Miao J, Zhu Z. Morphological variety of the soft palate in normal individuals: A digital cephalometric study. Dentomaxillofac Radiol, 2008; 37(6):344-9.

8. White S, Pharoah M. Oral Radiology Principles and Interpretation, 6 ed., Philadelphia: Mosby Elsevier, 2011, pp. $207-12$.

9. Subtelny JD. A cephalometric study of the growth of the soft palate. Plastic Reconstructive Surgery. 1957; 19:49-62.

10. Stellzig-Eisenhaver A. The influence of cephalometric parameters on resonance of speech in cleft lip and palate patients: An interdisciplinary study. J Orofacial Orthoped/ Fortschritte der Kieferorthopädie, 2001; 62:3:202-3.

11. Akcam MO, Toygar TU, Wada T. Longitudinal investigation of soft palate and nasopharyngeal airway relations in different rotation types. Angle Orthod, 2002; 72:6:521-6.

12. Mazaheri M, Krogman W, Harding R, Millard R, Mehta S. Longitudinal analysis of growth of the soft palate and nasopharynx from six months to six years. Cleft Palate J, 1977; 14:52-62.

13. Cohen SA, Chen L, Trotman CA, Burdi AA. Soft-palate myogenesis: A developmental field paradigm. Cleft Palate Craniofac J, 1993 : 441-6.

14. Taylor M, Hans MG, Strohl KP, Nelson S, Holly Broadbent B. Soft tissue growth of the oropharynx. Angle Orthod, 1996; 66:5:393-400.

15. Niu YM, Wang H, Zheng Q, He X, Zhang J, Li XM, LU Y. Morphology of the soft palate in normal humans with digital cephalometry. West China J Stomatol, 2006; 24:321-2,327.

16. Johnston $\mathrm{CH}$, Richardson A. Cephalometric changes in adult pharyngeal morphology. Euro J Orthod, 1999; $21: 4: 357-62$.

17. Samdani D, Saigal A, Garg E. Correlation of morphological variants of soft palate and types of malocclusion: A digital lateral cephalometric study. J Ind Acad Oral Medicine Radiol, 2015; 27:3:366-71.

18. Verma P, Verma KG, Kumaraswami KL, Basavaraju S, Sachdeva SK, Juneja S. Correlation of morphological variants of the soft palate and Need's ratio in normal individuals: A digital cephalometric study. Imaging Sci Dent, 2014.

19. Tejavathi Nagaraj RDG, James L, Sreelakshmi N, Veerabasavaiah BT, Shruthi R. A radiographic assessment of morphologies of soft palate: A Retrospective study. J Med Radiol Pathol Surg, 2016; 3:5:1-4.

20. Bhagwan C, Saha N, Vijayvargiya R. Morphological study of soft palate by using computed tomography: A prospective study. J Clin Diagn Res, 2015: 9 .

21. Krishnamurthi V, Singh P. Pagare SS. Normative soft palate dimensions and morphology in a subset of Indian population: A digital cephalometric study. Ind J Oral Health Res, 2015; 1:48-51.

22. Pepin J, Veale D, Ferretti G, Mayer P, Levy P. Obstructive Sleep Apnea Syndrome: Hooked appearance of the soft palate in awake patients: Cephalometric and CT findings," 1999.

23. Guttal KS, Breh R, Bhat R, Burde KN. and Naikmasur VG. Diverse morphologies of soft palate in normal individual: A cephalometric perspective. J Ind Acad Oral Med Radiol, 2012; 24:1:15-9. 